\title{
Sub-active Toxicity Effects of Iron Oxide Nanoparticles on Organs in Male Mice
}

\author{
Mary B. Ajadi ${ }^{1}$, Olubunmi G. Ayelagbe 1 ${ }^{*}$, Oluyemi Akinloye ${ }^{2}$
}

${ }^{1}$ Departments of Chemical Pathology, College of Health Sciences, Osogbo, Ladoke Akintola University of Technology, Ogbomoso, Nigeria

${ }^{2}$ Department of Biomedical Laboratory Sciences, University of Lagos, Akoka, Nigeria

*Correspondence should be addressed to Ayelagbe G. Olubunmi: bunmi.ayelagbe@gmail.com

Received 04 November 2019; Revised 18 December 2019; Accepted 19 December 2019

(C) 2019 Omotayo et al. Licensee Pan African Journal of Life Sciences. This is an Open Access article distributed under the terms of the Creative commons Attribution License (https://creativecommons.org/licenses/BY/4.0), which permits unrestricted use, distribution, and reproduction in any medium, provided the original work is properly cited.

Background: Decreased particle size and increased surface area to volume ratio are beneficial properties of nanoparticles. However, there are contrasting reports on their potential organotoxic effects. The dose dependent toxicity effects of iron III oxide nanoparticles $\left(\mathrm{Fe}_{2} \mathrm{O}_{3} \mathrm{NPs}\right)$ on the biochemical indices and histology of selected organs of adult male mice were investigated.

Methods: Fifty six male mice weighing between 25-32g were randomly assigned into 4 groups ( $\mathrm{n}=14$ ), the control/group 1 was given the vehicle/distilled water, while animals in groups (2-4) received $5 \mathrm{mg} / \mathrm{kg}, 25 \mathrm{mg} / \mathrm{kg}$ and $50 \mathrm{mg} / \mathrm{kg}$ body weights of $\mathrm{Fe}_{2} \mathrm{O}_{3} \mathrm{NPs}$ (INP) respectively by intraperitoneal route of administration for 14 days after which blood samples were drawn for biochemical analysis. Histopathology studies on the effect of graded doses of INP on the architecture of the liver, kidney and testes of mice were carried out.

Results: There were significant increases in plasma sodium, creatinine, urea, chloride, albumin, alanine and aspartate aminotransferases (ALT and AST) in the experimental animals after the 7th and 14th days of administration of graded doses of INP compared with the control group $(\mathrm{p}<0.05)$. These changes were dose-dependent. Photomicrographs showed morphological alterations including kupffer cells hyperplasia, hepatocyte necrosis, interstitial nephritis and eosinophilia of the renal tubular cells but only mild reduction in spermatid formation in testes at 25 and $50 \mathrm{mg} / \mathrm{kg}$ dosage respectively.

Conclusion: The Administration of INP brought about dose-dependent alterations in plasma markers of renal functions as well as hepatic enzymes activity. Deleterious morphological changes in architecture of the liver and kidney as well as mild changes in testes of mice were associated with INP administration

Keywords: Iron III oxide, nanoparticles, toxicity, liver, kidney, testis 


\subsection{INTRODUCTION}

Nanoparticles (NPs) are advantageous for medical and industrial use due to their decreased particle size and increased surface area to volume ratio at the nanoscale [1]. Nanoparticles such as nanodiamonds with protein molecules attached are used to increase bone growth around dental or joint implants, chemotherapy drugs attached to nanoparticles are also utilized in the treatment of brain tumors and leukemia [2,3]. Iron oxide nanoparticle has superparamagnetic properties and with applications in in vivo tracking, magnetic resonance imaging and induction of hypertemia in cancer treatment $[1,4]$. However, the interaction of nanoparticles with body organs and other biological systems have been known to elicit attendant toxic effects thereby warranting an in-depth understanding of their toxicity so as to prevent any potential harmful effects on human body $[5,6]$. For example, $\mathrm{ZnO}$ nanoparticles are reported to stimulate toxic effects on endothelial cells, liver and kidney and cause significant decrease in sperm count and vitality $[7,8]$. An in vivo study demonstrated the nephrotoxic potential of nanoparticles both at the tubular and glomerular levels [9].

High levels of INP with diameter $>100 n$ m are reported to be trapped in liver and could accumulate in hepatocytes triggering oxidative stress with generation of reactive oxygen species. This phenomenon, if sustained could lead to cell death while INP with diameter $<10 \mathrm{~nm}$ are likely to be eliminated through renal clearance [4]. An experiment using animal models revealed an inflammation of epididymis, increase in generation of free radicals and significant reduction in sperm numbers and mobility in male mice administered INP [10]. Administration of high doses of iron oxide nanoparticles has been shown to have undesirable effects on the liver with damage to hepatocytes and elevation of liver enzymes such as ALT, AST and ALP in serum [11].

Despite the growing literature on nanomaterials application, information about biological effects of Iron oxide nanoparticles on health and organ functions are often controversial $[10,12]$. This study investigated the toxic effect if any, of lower doses of $\mathrm{Fe}_{3} \mathrm{O}_{4}$ nanoparticles on liver, kidney and testis functions and histology in male mice.

\subsection{METHODOLOGY}

\subsection{Experimental Animals}

Fifty six (56) healthy adult male mice weighing between $25-32 \mathrm{~g}$ were utilized as experimental animals in this this is a cause-effect experimental study. The animals were obtained from LadokeAkintola University of Technology Biomedical Sciences Animal Research
Centre, Osogbo, Nigeria. They were kept under standard laboratory conditions of $12 \mathrm{~h}$ light and $12 \mathrm{~h}$ dark cycle, temperatures of $65-75^{\circ} \mathrm{F} \quad\left(\sim 18-23^{\circ} \mathrm{C}\right)$ with $40-60 \%$ humidity throughout the experimental period. Animals were kept in clean cages and commercial food (pellet) and water were provided ad libtum. The animals were allowed to acclimatize for one week before commencement of the study.

\subsection{Experimental Design}

The male mice were divided into three test groups of 14 animals each and a fourth control group. The animals were injected intraperitoneally with graded doses of Iron III oxide nanoparticles (INP) for 2 weeks (Table 1).

Table1: Doses of INP Administered to Experimental Animals for 2 Weeks

\begin{tabular}{cl}
\hline Groups & INP Dose (mg/kgBW) \\
\hline $1(\mathrm{n}=14)$ & 5 \\
$2(\mathrm{n}=14)$ & 25 \\
$3(\mathrm{n}=14)$ & 50 \\
$4(\mathrm{n}=14)$ & distilled water and food pellet \\
\hline
\end{tabular}

The nanoparticles used in this study were polymer capped $\mathrm{nFe}_{2} \mathrm{O}_{3}$ provided by Vive Crop Protection (Toronto, Canada). These are small $(<10 \mathrm{~nm})$ negatively charged metal oxide engineered nanoparticles (ENP) $\left(\mathrm{Fe}_{2} \mathrm{O}_{3}\right)$ that were functionalized with a polyacrylic acid polymer coating. The functionalization makes these ENPs highly dispersible and stable in suspension. The properties of these nanoparticles in solution are well characterized as previously published [13]. All chemicals used in this study were of analytical grade and obtained from Sigma (St. Louis, USA).

The study protocol was approved by the Ethical Committee of Ladoke Akintola University of Technology, Osogbo Campus, Nigeria.

\subsection{Sample Collection and Storage}

The treated animals and the control group were anesthetized using ether, bled via cardiac puncture, blood samples drawn into lithium heparinized bottles and then sacrificed. The samples were centrifuged at 100orpm for 15 minutes using Uniscope Laboratory Centrifuge (Model 5 m112 Surgifriend Medics, England). Plasma samples were collected and stored in a refrigerator at - $200 \mathrm{c}$ until laboratory analysis. Biochemical and histological investigations of liver, kidney and testis tissues were carried out.

\subsection{Biochemical Analysis}

Plasma albumin was estimated based on the bromocresol green method (AgappeDiagnostics, Switzerland). Total protein and liver enzymes alanine aminotransferase and 
AST were analyzed using marketed reagent (Randox laboratory limited, Crumlin, County Antrim, UK), ALP by direct colorimetric endpoint method (Teco diagnostics, Lakeview Ave, Anaheim, CA). Plasma electrolytes, urea and creatinine were determined using auto analyzer (902 Hitachi Automatic Analyzer, Roche, India). Testosterone, luteinizing hormone (LH) and follicle stimulating hormones (FSH) were quantitatively determined by microplate immunoenzymometric assay (Monobind Inc., Lake Forest, CA, USA).

\subsection{Histopathological Investigation}

Samples of liver, testis and kidney tissues were excisedfrom all experimental mice after deep etheranesthesia. After removal, the tissues were immediately fixed in 10\% formalin overnight while testis was fixed in Bouin's solution. The tissues were embedded in paraffin, cutinto $5 \mu \mathrm{m}$ sections, placed on slides and stained with Hematoxylin- Eosin (H\&E) beforehistopathological examination. The tissue sections were viewed under a light microscope (Nikon Y-100, Germany) magnification of x100.

Statistical analyses were performed using SPSS 20.0 (SPSS Korea Data Solution, Seoul, Korea) software package. Means of all parameters were calculated for each group. One- way analysis of Variance (ANOVA) was used to determine significant differences between the groups. Pairwise comparisons were made using Tukey Kramer Multiple Comparisons Post hoc test at Statistical at $\mathrm{p}<0.05$.

\subsection{RESULTS}

The mean values of analysed biochemical parameters in all experimental animals in group 1 administered with $5 \mathrm{mg} / \mathrm{kg}$ dose of INP were summarized in Table 2. There were significant changes in plasma level of all parameters except potassium, urea, ALT and ALP on day 7 compared with the value in unexposed controls $(\mathrm{p}<0.05)$. Decreased plasma urealevel (day 1) and ALT activity (day 7) were observed in comparison with that recorded on day $14(\mathrm{p}<0.05)$ and $(\mathrm{p}<0.01)$ respectively. No mortality was recorded throughout the period of the experiment.

Table 3 showed the pattern of changes in biochemical parameters measured after administering engineered INP at $25 \mathrm{mg} / \mathrm{kg}$ body weight. On day 7 , the level of potassium (K) was highest in the test animals compared to days 1 and $14(\mathrm{p}<0.01)$. The highest value of all other parameters were recorded on day 14 in experimental animals than the control group with significant changesseenin concentrations of $\mathrm{Na}, \mathrm{Cl}^{-}$, urea, Alb, TPin addition to AST and ALT activities ( $\mathrm{p}<0.05)$.

After the administration of $50 \mathrm{mg} / \mathrm{kg}$ Iron III oxide nanoparticle, $\mathrm{Cl}^{-}$and urea concentrations as well as ALT
Table 2: Changes in biochemical parameters/day in mice after administration of $5 \mathrm{mg} / \mathrm{kg}$ INP $(\mathrm{n}=14)$

\begin{tabular}{|c|c|c|c|c|}
\hline Parameters & Control & Day 1 & Day 7 & Day 14 \\
\hline$\overline{\mathrm{K}(\mathrm{mmol} / \mathrm{l})}$ & $4.30 \pm 0.69$ & $4.28 \pm 0.6$ & $4.33 \pm 0.76$ & $4.43 \pm 1.08$ \\
\hline $\mathrm{Na}(\mathrm{mmol} / \mathrm{l})$ & $\begin{array}{l}125 \cdot 85^{ \pm 19} \\
.96^{*}\end{array}$ & $\begin{array}{l}\text { o } \\
134.00 \pm 2 \\
8.54\end{array}$ & $\begin{array}{l}146.06 \pm 2 \\
0.81\end{array}$ & $\begin{array}{l}162.00 \pm 4 . \\
68^{*}\end{array}$ \\
\hline $\mathrm{HCO}_{3}^{-}$ & $19.71 \pm 3.77$ & $20.00 \pm 0$ & $22.66 \pm 3.0$ & $23.75 \pm 1.38$ \\
\hline $\mathrm{Cl}^{-}(\mathrm{mmol} / \mathrm{l})$ & $\begin{array}{l}110.14 \pm 12 . \\
17^{*}\end{array}$ & $\begin{array}{l}116.31 \pm 2 . \\
50\end{array}$ & $\begin{array}{l}5 \\
123 \cdot 33 \pm 3 . \\
51^{*}\end{array}$ & $\begin{array}{l}139.25 \pm 16 . \\
O 1^{*}\end{array}$ \\
\hline Urea(mmol/ & $17.70 \pm 3.4$ & $17.70 \pm 2.6$ & $21.63 \pm 3.4$ & $24.83 \pm 4.8$ \\
\hline $\begin{array}{l}\text { l) } \\
\mathrm{Cr}^{-}(\mathrm{umol} / \mathrm{l})\end{array}$ & $\begin{array}{l}5 \\
117.71 \pm 16 .\end{array}$ & $\begin{array}{l}\mathrm{O}^{*} \\
121.33 \pm 1\end{array}$ & $\begin{array}{l}4 \\
225.66 \pm 9\end{array}$ & $\begin{array}{l}7^{*} \\
390.00 \pm 70\end{array}$ \\
\hline $\mathrm{LH}(\mathrm{m} / \mathrm{U} / \mathrm{ml})$ & $\begin{array}{l}\mathrm{O}^{*} \\
1.31 \pm 0.17^{*}\end{array}$ & $\begin{array}{l}9.03 \\
1.75^{ \pm 0.11}\end{array}$ & $\begin{array}{l}0.0 \\
1.75 \pm 0.11\end{array}$ & $\begin{array}{l}.4^{*} \\
2.29 \pm 0.54^{*}\end{array}$ \\
\hline $\mathrm{FSH}$ (ng/ml) & $\begin{array}{l}0.47 \pm 0.08 \\
*\end{array}$ & $\begin{array}{l}0.56 \pm 0.1 \\
8\end{array}$ & $\begin{array}{l}1.22 \pm 0.57 \\
*\end{array}$ & $1.23 \pm 0.17^{*}$ \\
\hline $\begin{array}{l}\text { Testosterone } \\
\mathrm{m} / \mathrm{U} / \mathrm{ml}\end{array}$ & $\begin{array}{l}0.27 \pm 0.15 \\
*\end{array}$ & $\begin{array}{l}0.37 \pm 0.0 \\
5\end{array}$ & $0.51 \pm 0.11$ & $\begin{array}{l}0.55 \pm 0.68 \\
*\end{array}$ \\
\hline $\mathrm{Alb}(\mathrm{g} / \mathrm{l})$ & $\begin{array}{l}15.86 \pm 2.1 \\
9^{*}\end{array}$ & $\begin{array}{l}18.33 \pm 1.5 \\
2\end{array}$ & $\begin{array}{l}25 \cdot 33 \pm 7 \cdot 5 \\
7\end{array}$ & $\begin{array}{l}30.25 \pm 3.91 \\
*\end{array}$ \\
\hline $\mathrm{TP}(\mathrm{g} / \mathrm{l})$ & $\begin{array}{l}29.14 \pm 4.1 \\
4^{*}\end{array}$ & $\begin{array}{l}32.33 \pm 2 . \\
31\end{array}$ & $\begin{array}{l}42.00 \pm 4.5 \\
8^{*}\end{array}$ & $\begin{array}{l}43.25 \pm 5.9 \\
\mathrm{O}^{*}\end{array}$ \\
\hline AST (IU/L) & $\begin{array}{l}79.43 \pm 10 . \\
74^{*}\end{array}$ & $\begin{array}{l}80.67 \pm 6 . \\
11\end{array}$ & $\begin{array}{l}94.667 \pm 5 . \\
03\end{array}$ & $\begin{array}{l}131.87 \pm 9.2 \\
3^{*}\end{array}$ \\
\hline ALT (IU/L) & $24.43 \pm 2.4$ & $26.00 \pm 8$ & $31.00 \pm 5.2$ & $44 \cdot 37 \pm 12 \cdot 4$ \\
\hline ALP (IU/L) & $\begin{array}{l}4 \\
74.54 \pm 5.8 \\
4\end{array}$ & $\begin{array}{l}72 \\
73 \cdot 71 \pm 6.4 \\
4\end{array}$ & $\begin{array}{l}9^{\dagger} \\
75.24 \pm 3.1 \\
9\end{array}$ & $\begin{array}{l}8^{\dagger} \\
73.84 \pm 3.75\end{array}$ \\
\hline
\end{tabular}

significant@ ${ }^{*} \mathrm{p}<0.001, \quad \# \mathrm{p}<0.05,+\mathrm{p}<0.01$; K-Potassium, Na- Sodium, Cr-Creatinine, LH- luitenizing hormone, FSH - follicle stimulating hormone, AlbAlbumin, TP-Total protein, AST- aspartate aminotransferase, ALT - alanine aminotransferase, ALP - alkaline phosphatase

activity were significantly increased in treated groups on 14th day compared to unexposed controls. Interestingly, even as early as $24 \mathrm{~h}$ of INP injection, higher values of testosterone $(\mathrm{p}<0.05), \mathrm{Na}^{+}$, total protein and AST activity were observed $(\mathrm{p}<0.01)$ (Table 4$)$.

\subsection{Histological Findings}

Figure 1 revealed the photomicrograph of pathological section of liver after injection with $5 \mathrm{mg} / \mathrm{kg}$ of INP on day 14. Hepatocyte balloon degeneration in zones 2 and 3 , normal hepatocytes in zone 1, occasional foci of hepatocyte necrosis and scanty eosinophils were seen. The photomicrograph of the pathological section of the liver after injection with $25 \mathrm{mg} / \mathrm{kg}$ of INP on day 14 was shown in Figure 2. Kupffer cells hyperplasia, marked portal vein congestion, diffuse hepatocyte balloon degeneration, numerous foci of hepatocyte necrosis surrounding central veins and focal congestion of sinusoids were observed. 
Table 3: Changes in analyzed biochemical parameters/ day $($ mean \pm SD) in animals administered $25 \mathrm{mg} / \mathrm{kgBW}$ INP $(n=14)$

\begin{tabular}{lllll}
\hline Parame- & Control & Day 1 & Day 7 & Day 14 \\
ters & & & & \\
\hline $\mathrm{K}(\mathrm{mmol} / \mathrm{l})$ & $4.30 \pm 0.69$ & $3.87 \pm 0.11^{* *}$ & $5.17 \pm 0.73^{* *}$ & $4.55 \pm 1.56^{* *}$ \\
$\mathrm{Na}(\mathrm{mmol} / \mathrm{l})$ & $125.85 \pm 20.0^{*}$ & $143.33 \pm 5.77$ & $150.0 \pm 10.0$ & $165.0 \pm 16.90^{*}$ \\
$\mathrm{HCO}_{3}^{-}$ & $19.71 \pm 3.77$ & $22.00 \pm 2.64$ & $24.33 \pm 3.21$ & $27.75 \pm 2.49$ \\
$(\mathrm{mmol} / \mathrm{l})$ & & & & \\
$\mathrm{Cl}^{-}(\mathrm{mmol} / \mathrm{l})$ & $110.14 \pm 12.2^{*}$ & $119.67 \pm 5.69$ & $126.0 \pm 13.11$ & $144.25 \pm 3.15^{*}$ \\
$\mathrm{Urea}$ & $17.70 \pm 3.45^{\#}$ & $21.00 \pm 6.10$ & $23.63 \pm 5.20$ & $25.32 \pm 2.86^{\#}$ \\
$\mathrm{mmol} / 1$ & & & & \\
$\mathrm{Cr}(\mathrm{umol} / \mathrm{l})$ & $117.71 \pm 16.0$ & $213.67 \pm 38.76^{*}$ & $334.67 \pm 38.76$ & $390.0 \pm 70.42^{*}$ \\
$\mathrm{LH}(\mathrm{m} / \mathrm{U} / \mathrm{ml})$ & $1.31 \pm 0.17^{*}$ & $1.52 \pm 0.52$ & $2.83 \pm 0.68$ & $3.78 \pm 0.33^{*}$ \\
$\mathrm{FSH}(\mathrm{m} / \mathrm{U} /$ & $0.47 \pm 0.08^{*}$ & $0.67 \pm 0.34$ & $1.29 \pm 0.61$ & $1.55 \pm 0.41^{*}$ \\
$\mathrm{ml})$ & & & & \\
$\mathrm{Testosterone}$ & $0.27 \pm 0.15^{*}$ & $0.38 \pm 0.06$ & $0.57 \pm 0.29$ & $0.81 \pm 0.30^{*}$ \\
$\mathrm{ng} / \mathrm{ml}$ & & & & \\
$\mathrm{Alb}(\mathrm{g} / \mathrm{l})$ & $15.86 \pm 2.19^{\# *}$ & $20.67 \pm 3.05^{\#}$ & $27.0 \pm 7.54$ & $30.87 \pm 2.53^{*}$ \\
$\mathrm{TP}(\mathrm{g} / \mathrm{l})$ & $29.14 \pm 4.14^{*}$ & $33.33 \pm 0.58$ & $39.0 \pm 7.00$ & $51.50 \pm 7.44^{*}$ \\
$\mathrm{AST}(\mathrm{IU} / \mathrm{L})$ & $79.43 \pm 10.74^{*}$ & $84.33 \pm 10.01$ & $100.67 \pm 20.52$ & $130.88 \pm 9.23^{*}$ \\
$\mathrm{ALT}(\mathrm{IU} / \mathrm{L})$ & $24.43 \pm 2.44^{*}$ & $26.00 \pm 11.36$ & $33.33 \pm 7.76^{* *}$ & $48.25 \pm 8.37^{*}$ \\
$\mathrm{ALP}(\mathrm{IU} / \mathrm{L})$ & $74.54 \pm 5.84$ & $75.24 \pm 3.19$ & $73.71 \pm 6.44$ & $76.34 \pm 6.84$ \\
\hline
\end{tabular}

significant@ ${ }^{*} \mathrm{p}<0.001, \# \mathrm{p}<0.05,{ }^{\dagger} \mathrm{p}<0.01$

Figure 3 represents the photomicrograph of pathological section of liver after administration of $50 \mathrm{mg} / \mathrm{kg}$ of INP on day 14. This showed congestion of portal vein, foamy degeneration of hepatocytes and focal areas of hepatocyte necrosis. The histopathological findings of the section of kidney of mice after injection with $5 \mathrm{mg} / \mathrm{kg}$ of INP on day 14 showed focal areas of vacuolation and widespread eosinophilia of renal tubular cells as well as a reduction in tubular lumen size (Figure 4).

Histological changes of congestion of renal intertubular veins and glomerular capillaries, interstitial nephritis with focal lymphocytic aggregates in kidney tissue after injection with $25 \mathrm{mg} / \mathrm{kg}$ of INP was observed on day 14 (Figure 5). As shown in Figure 6, there were congestion at vascular channels in medulla and pelvis, widespread vacuolation at renal tubule cells and mild atrophy of renal tubules after administration of $50 \mathrm{mg} / \mathrm{kg}$ of INP on day 14 in experimental animals. The histopathological examination of the testis tissue did not show a significant alteration for all the tested doses (photomicrographs not shown). At $5 \mathrm{mg} / \mathrm{kg}$, normal seminiferous tubules and mild reduction in spermatid formation was recorded. At $25 \mathrm{mg} / \mathrm{kg}$ a mild reduction in thickness of seminiferous tubules and in spermatogenic cells was seen while at $50 \mathrm{mg} / \mathrm{kg}$ an observation of a mild reduction in spermatogenic cells and formation of spermatids was made.
Table 4: Changes in biochemical parameters (mean \pm SD)after administration of $50 \mathrm{mg} / \mathrm{kgBW} \operatorname{INP}(\mathrm{n}=14)$

\begin{tabular}{|c|c|c|c|c|}
\hline $\begin{array}{l}\text { Param- } \\
\text { eters }\end{array}$ & Control & Day 1 & Day 7 & Day 14 \\
\hline $\mathrm{K}(\mathrm{mmol} / \mathrm{l})$ & $4.30 \pm 0.69 * \#$ & $4.43 \pm 1.20$ & $5.53 \pm 0.68 \#$ & $6.08 \pm 1.01^{*}$ \\
\hline $\mathrm{Na}(\mathrm{mmol} /$ & $125.85 \pm 19.96$ & $150.0 \pm 10.0 \dagger$ & $170.00 \pm 20.0 \dagger$ & $182.38 \pm 4.69 \dagger$ \\
\hline 1) & $\dagger$ & & & \\
\hline $\begin{array}{l}\mathrm{HCO}_{3} \\
(\mathrm{mmol} / \mathrm{l})\end{array}$ & $19.71 \pm 3.77$ & $24.00 \pm 3.46$ & $25.00 \pm 1.00$ & $28.75 \pm 2.54$ \\
\hline $\mathrm{Cl}^{-}(\mathrm{mmol} /$ & $110.14 \pm 12.17$ & $131.33 \pm 18.38$ & $141.33 \pm 11.59$ & $147.00 \pm 24.30$ \\
\hline 1) & $*$ & & & $*$ \\
\hline Urea & $17.70 \pm 3.45 \#^{*}$ & $22.70 \pm 6.61$ & $24.10 \pm 5.10 \#$ & $26.59 \pm 2.90 *$ \\
\hline $\begin{array}{l}\mathrm{mmol} / 1 \\
\mathrm{Cr}^{-}(\mathrm{umol} / \mathrm{l})\end{array}$ & $117.71 \pm 16.0 *$ & $326.00 \pm 77.95 \dagger$ & $384.00 \pm 41.76^{*}$ & $\begin{array}{l}406.00 \pm 75.47 \\
\dagger\end{array}$ \\
\hline $\mathrm{LH}(\mathrm{m} / \mathrm{U} /$ & $1.31 \pm 0.17 *$ & $2.63 \pm 0.98$ & $3.42 \pm 1.22 *$ & $2.64 \pm 1.15$ \\
\hline $\begin{array}{l}\mathrm{FSH}(\mathrm{m} / \mathrm{U} / \\
\mathrm{ml})\end{array}$ & $0.47 \pm 0.08 *$ & $0.72 \pm 0.27 \dagger$ & $1.37 \pm 0.76^{*}$ & $1.73 \pm 0.09 * \dagger$ \\
\hline $\begin{array}{l}\text { Testos- } \\
\text { terone }\end{array}$ & $0.27 \pm 0.15^{*}$ & $0.57 \pm 0.31^{*}$ & $0.77 \pm 0.05$ & $4.09 \pm 1.08^{*}$ \\
\hline $\mathrm{Alb}(\mathrm{g} / \mathrm{l})$ & $15.86 \pm 2.19 *$ & $23.33 \pm 5.51$ & $32.00 \pm 2.00 *$ & $30.87 \pm 5.11 *$ \\
\hline $\mathrm{TP}(\mathrm{g} / \mathrm{l})$ & $29.14 \pm 4.14 * \dagger$ & $34.66 \pm 2.31 \dagger$ & $42.00 \pm 4.58 *$ & $58.26 \pm 4.68 *$ \\
\hline $\operatorname{AST}(\mathrm{IU} / \mathrm{L})$ & $\begin{array}{l}79.43 \pm 10.74 * \\
\dagger \#\end{array}$ & $94.67 \pm 5.03 \dagger$ & $101.00 \pm 4.36^{* \#}$ & $\begin{array}{l}131.87 \pm 31.38 \\
*\end{array}$ \\
\hline $\operatorname{ALT}(\mathrm{IU} / \mathrm{L})$ & $24.43 \pm 2.44 \#$ & $30.00 \pm 4.36$ & $45.00 \pm 42.04$ & $53.63 \pm 19.14 \#$ \\
\hline $\operatorname{ALP}(\mathrm{IU} / \mathrm{L})$ & $73.44 \pm 5.84$ & $73.53 \pm 5.69$ & $77.80 \pm 6.83$ & $75.84 \pm 4.63$ \\
\hline
\end{tabular}

significant@ ${ }^{*} \mathrm{p}<0.001, \# \mathrm{p}<0.05,{ }^{\dagger} \mathrm{p}<0.01$

significant@ ${ }^{*} \mathrm{p}<0.001, \# \mathrm{p}<0.05,{ }^{\dagger} \mathrm{p}<0.01$

\subsection{DISCUSSION}

This study showed significantly raised AST, and ALT activities, albumin and total protein across the graded doses of investigated nanoparticles suggesting impaired hepatic function. This was similar to results from earlier studies $[14,15,16]$ although one study [16] reported a decrease in serum albumin. Hyperalbuminemia observed in this study could be attributed to the fact that the liver has been shown to be capable of synthesizing increased amount of albumin until the hepatic parenchymal damage is severe with loss of about 95\% function[17]. Minimal histological changes were observed in liver of mice in the present study at the $5 \mathrm{mg} / \mathrm{kg}$ dose of INP while the $25 \mathrm{mg} / \mathrm{kg}$ and $50 \mathrm{mg} / \mathrm{kg}$ doses appeared to bring about more significant alterations in hepatocyte architecture reflecting the adverse effect of the increased dose of the INP but no extensive damage to liver parenchymal was seen. This was in agreement with 


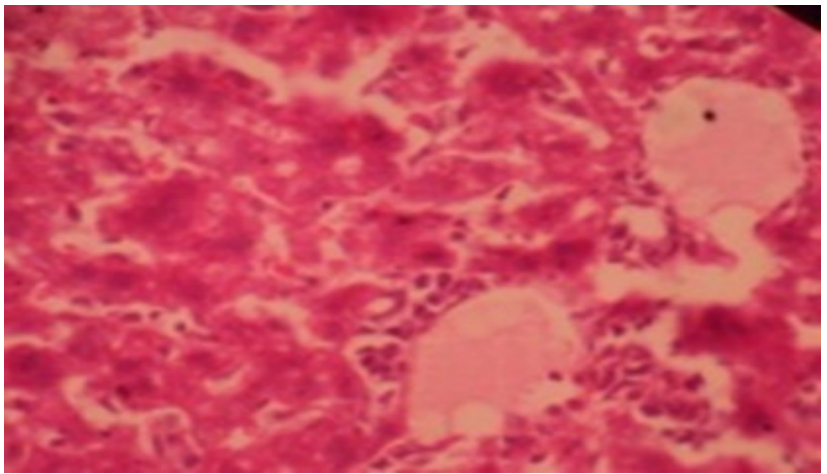

Figure 1: The photomicrograph of pathological section of liver after injection with $5 \mathrm{mg} / \mathrm{kg}$ of INP on day 14 (x100)

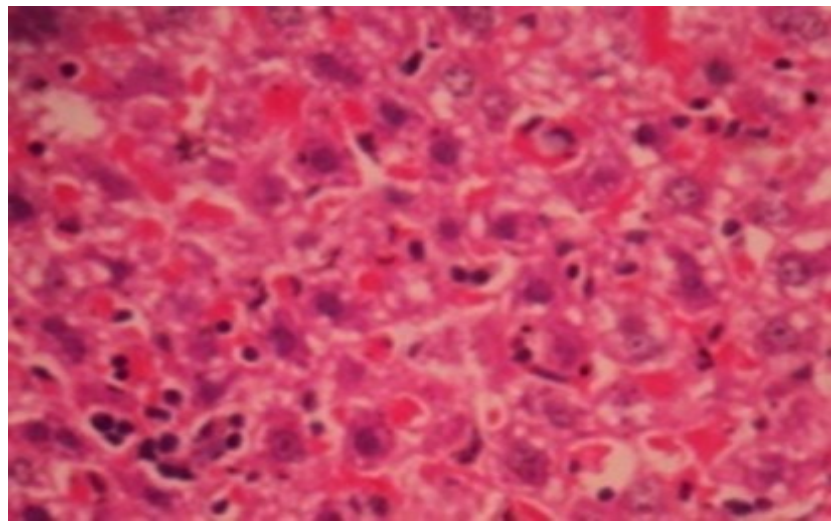

Figure 2: photomicrograph of pathological section of liver after injection with $25 \mathrm{mg} / \mathrm{kg}$ of INP on day 14 (x100)

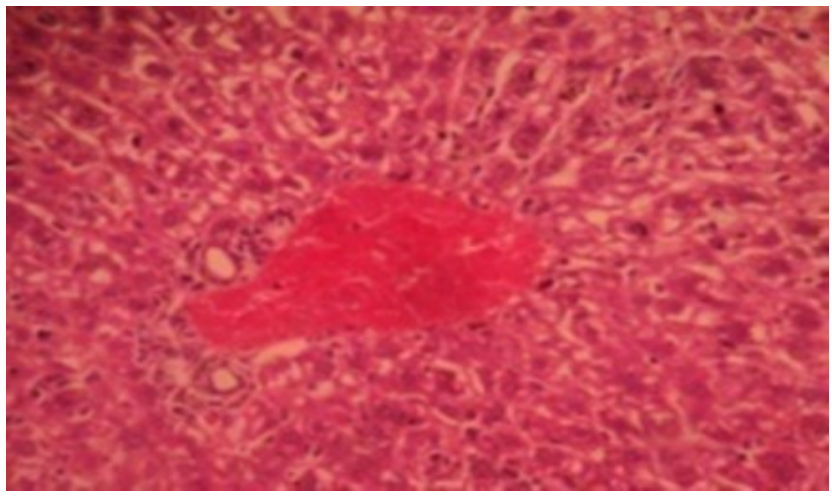

Figure 3: photomicrograph of pathological section of liver after injection with $50 \mathrm{mg} / \mathrm{kg}$ of INP on day 14 (x100)

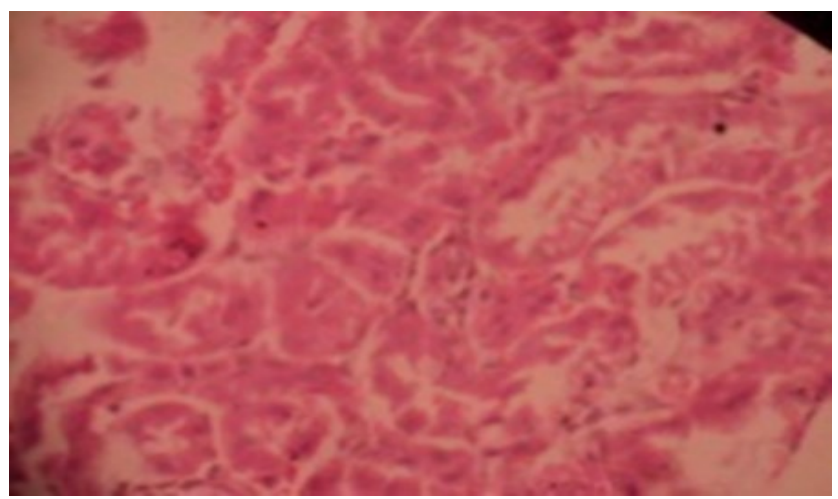

Figure 4: photomicrograph of pathological section of kidney after injection with $5 \mathrm{mg} / \mathrm{kg}$ of INP on day 14 (x100)

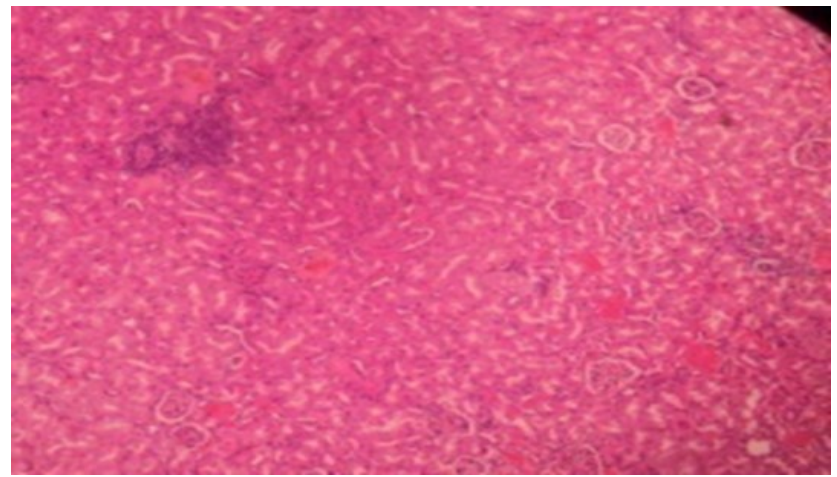

Figure 5: The photomicrograph of pathological section of kidney after injection with $25 \mathrm{mg} / \mathrm{kg}$ of INP on day 14 (x100)

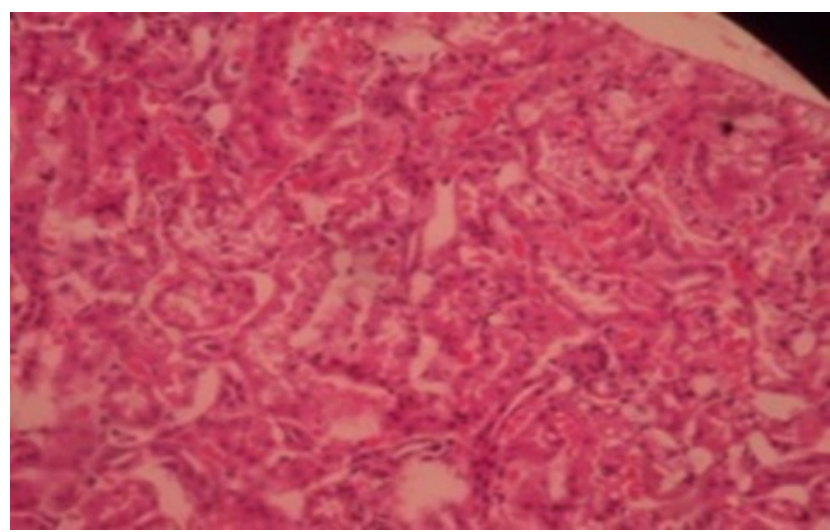

Figure 6: The photomicrograph of pathological section of kidney after injection with $50 \mathrm{mg} / \mathrm{kg}$ of INP (iron oxide nanoparticles) on day 14 (x100)

other study that reported significant increase in hepatic enzymes and histopathologic changes in hepatocytes in mice treated with $150 \mathrm{mg} / \mathrm{kg}$ as well as 150 and $300 \mu \mathrm{g} / \mathrm{gr}$ doses of INP but not in lower doses [11]. A possible mechanism for the toxicity of INP in the liver is the strong association of reactive oxygen species (ROS) generation to intracellular toxicity. Other possible mechanism is the accumulation of iron in the tissues and organs at high doses [1]. In fact, doses of 25 and $50 \mathrm{mg} /$ $\mathrm{kg}$ INP administration have been shown to increase the reactive oxygen species, lipid peroxidation, glutathione peroxidase activity, and nitric oxide levels with a concomitant decrease in the levels of antioxidants in experimental animals[18].

A possible route of elimination of nanoparticles is through renal excretion and the kidneys are also known to be susceptible to damage from xenobiotics [9]. Plasma electrolytes including sodium, chloride as well as markers of filtering ability (creatinine and urea) of the kidney were significantly raised in animals in the INP exposed groups than controls in this study. This could be suggestive of impaired kidney function and corroborated by the altered histological changes seen in kidney tissue of the test animals. In addition, a mild hypokalemia was observed after the first $24 \mathrm{hrs}$ of INP administration at 
$5 \mathrm{mg} / \mathrm{kg}$ and $25 \mathrm{mg} / \mathrm{kg}$ dosages while increased potassium levels were observed on day 7 and 14 using the same dose. This suggests a relationship between duration of exposure to nanoparticles and degree of toxicity which is at variance with a study that reported no changes in renal function indices after short term use of INP in rats[19]. Renal histopathological findings from this study showed features consistent with symptoms of acute kidney injury (AKI) [20] which suggests that INP is nephrotoxic at tested doses.

Testosterone functions in the regulation of spermatogenesis, FSH and LH are both gonadotrophic hormones which act on leydig cells of the testis to induce the synthesis and secretion of testosterone [21]. This investigation, with respect to testicular function, plasma testosterone, FSH and LH were all significantly raised in the experimental mice administered 5omg/ $\mathrm{kg}$ INP dose compared to the control group. Elevated levels of LH and FSH were associated with primary testicular failure [22] thus, suggesting the potential testicular toxicity of INP. Other studies involving iron nanoparticle have reported their harmful effects on male reproductive system causing infertility $[23,24]$. Nanoparticles were shown to cross Blood Testes Barrier (BTB) which enhances their toxicity in the male reproductive system [25]. Exposure to metal nanoparticles such as Iron increases generation of reactive oxygen species which may inhibit RNA polymerase and cause the oxidation of molecules such as protein and DNA. This may cause undesirable changes in LH and testosterone which are the major hormones produced by the testis $[26,27]$. This interferes with testicular function often resulting in reduction in spermatid formation leading to reduced spermatogenesis associated with male infertility [21]. The histological study of testis here did not reveal significant adverse distortions in the cells. This was in contrast to another work that reported meaningful reduction in sperm numbers and mobility in all experimental groups as well as inflammation of the epididymis [10]. These variations could be largely due to duration of exposure, concentration and the animal species[8]. Although this study was experimented with small number of animals with short duration of exposure, the results obtained therein showed the toxic effects of iron (III) oxide nanoparticle at short term and even low doses on the different organs studied. A further study involving a larger sample size and longer period of exposure is envisaged to validate our result.

\section{Acknowledgements}

Authors appreciate the kind gesture of Prof. Goss Greg of Department of Biology, University of Alberta, Canada for donating the iron oxide nanoparticles. The technical staff of the
Department of Histopathology, LAUTECH, Ogbomoso, Nigeria assisted in the histological studies.

\section{Conflict of interest}

The authors declare that they have no conflicts of interest.

\section{Authors Contribution}

MBA collected data, contributed to analysis tools and performed data analysis. OGA drafted and revised the manuscript, supervised laboratory analysis. $\mathbf{O A}$ conceived and designed the study, and contributed to laboratory reagents

\section{References}

1. Feng Q, Liu Y, Xiao K. Uptake, distribution, clearance and toxicity of iron oxide nanoparticles with different sizes and coatings. Scientific reports.2018, 8: article no: 2082, doi: 10.1038/s41598-018-19628-z.

2. Moore L, Gatica M, Kim H, Osawa E. Multi-protein delivery by nanodiamonds promote bone formation. J Dent Res. 2013; 92(11):976-981.

3. Tsai L, Lin Y, Perevedentseva E. Nanodiamonds for medical applications: interaction with blood in vitro and in vivo. J Mol Sci. 2016; 17(7): 1111. Doi: 10.3390/ijms17071111.

4. Naqvi S. Concentration-dependent toxicity of Iron oxide nanoparticle mediated by increased oxidative stress. Int $\mathbf{J}$ Nanomedicine. 2010; 5, 983-989.

5. Schilling K, Bradford B, Castelli D, Dufour E, Nash JF, Pape W. Human safety review of "nano" titanium dioxide and zinc oxide. PhotochemPhotobiol Sci. 2010; 9: 495-509.

6. Sharma V, Singh P, Pandey AK,Dhawan A. Induction of oxidative stress, DNA- damage and apoptosis in mouse liver after sub-acute oral exposure to zinc oxide nanoparticles. Mutat Res. 2012; 745: 84-91.

7. Shirvani H, Noori A,Mashayekh AM. The Effect of $\mathrm{ZnO}$ Nanoparticles on the Growth and Puberty of Newborn Male Wistar Rats. International Journal of Basic Sciences and Applied Research. 2014; 3(suppl):180-185. ISSN 21473749.

8. Wang B, Feng W, Wang M. Acute toxicological impact of nano-and submicro-scaled zinc oxide powder on healthy adult mice. J Nanopart Res. 2008; 10(2):263-276.

9. Iavicoli I, Fontana L, Nordberg G. The effects of nanoparticles on the renal system. Critical Reviews in Toxicology. 2016, 46(6):490-560.

10. Nasri S, Rezai-Zarchi S, Kerishchi P,Sadeghi S. The Effect of Iron Oxide Nanoparticles on Sperm Numbers and Mobility in Male Mice. Zahedan Journal of Research in Medical Sciences.2015; doi. 10.17795/zjrms-2185.

11. Vahid BY, Leila N, Azadeh N, Hosein G, Mohammad EBZ. Evaluation of iron oxide nanoparticles effects on tissue and enzymes of liver in rats. J Pharm Biomed Sci. 2012; 23 (23):1-4.

12. Adamcakova-Dodd A , Stebounova LV, Kim JS , Vorrink SU, Ault AP. Toxicity assessment of zinc oxide nanoparti- 
cles using sub-acute and sub-chronic murine inhalation models. Particle and Fibre Toxicology. 2014;11:15 doi: 10.1186/1743- 8977-11-15

13. Jeong-Sup H, Myeong-Kyu P, Min-Seok K, Jeong-Hyeon L, Gil-Jong P.Prenatal development toxicity study of zinc oxide nanoparticles in rats. Int $J$ Nanomedicine. 2014; (Suppl 2):159-171

14. Esmaeilloua M, Moharamnejada M, Hsankhani R, Tehrani AA,Maadi H. Toxicity of $\mathrm{ZnO}$ nanoparticles in healthy adult mice. Environmental toxicology and pharmacology. 2018; 3 (5): 67-71.

15. Sadeghi L, Tanwir F, Babadi V. In vitro toxicity of iron oxide nanoparticle: oxidative damages on Hep G2 cells. J Gesell ToxikolPathol. 2015; 67(2):197-203.

16. Adeyemi OS, Sulaiman FA, Akanji MA, Oloyede HOB, Sulaiman AA. Biochemical and morphological changes in rats exposed to platinum nanoparticles. Comparative clinical pathology ausgabe. 2016; 6(5): 4-7.

17. Lee WM. Acetaminophen and the US. Acute Liver Failure Study Group: lowering the risks of hepatic failure. Hepatology. 2004; 40: 6-9

18. Babadi VY, Najafi L, Najafi A, Gholami H, Beigizarji M. Effects of iron nanoparticle on function of liver. Pharma Biomed Sci. 2012; 28: 1-5

19. Salehi M, Fatahlan S,Shahanipour K. Effect of iron oxide nanoparticles coated with chitosan on renal functional indices in rats. J Gorgan Uni. Med. Sci. 2017; 19(1): pp Pe 14Pe 18.

20. Sundarraj K, Manickam V, Raghunath A,PerumalE. Repeated exposure to iron oxide nanoparticles causes testicular toxicity in mice. Environmental Toxicology.2016;doi: 10.1002/tox.22262.

21. Lehtil MS,Sironen A. Formation and function of the manchette and flagellum during spermatogenesis. J. of Society for Reproduction and infertility. 2016; 151:21-5.

22. Lo KC, Lamb DJ. The testis and male accessory organs. In: Strauss J,Barberi R, editors. Yen and Jaffe's reproductive endocrinology: physiology, pathophysiology and clinical management. 5th ed. Philadelphia: Saunders; 2004.p21354 .

23. National Kidney Foundation - K/DOQ. Clinical practice guidelines for chronic kidney disease: evaluation, classification and stratification. Am J Kidney Dis. 2002; 39:1-266.

24. National Kidney Foundation - K/DOQ. Clinical practice guidelines for chronic kidney disease: evaluation, classification and stratification. Am J Kidney Dis. 2002; 39(suppl 1):S1-266.

25. Noori A, Karimi F, Fatahian S,Yazdani F. Effects of zinc oxide nanoparticles on renal function in Mice, Int. J. Biosci. 2014; http://dx.doi.org/10.12692/ijb/5.9.140-146.

26. Braydich-Stolle LK, Lucas B, Schrand A, Murdock RC, Lee T. Silver nanoparticles distrupt GDNF/Fyn kinase signaling in spermatogonial stem cells. Toxicological science. 2010; 116(2):577-589.

27. Yoshida Y, Itoh N, Saito Y. Application of water soluble radical initiator, 2, 2-azobis [2-(2-1 imidazolin-2- yi) propane] dihydro chloride to a study of oxidative stress. Free Radic Res. 2004; 38(4): 375-84.

28. Stocco DM. The role of StAR protein in steroidogenesis: Challenges for the future. J Endocrinol. 2000; 164(3): 24753 